\section{Abundances of Meteoric Lead Isotopes}

IN a recent publication Patterson ${ }^{1}$ shows that the measured isotopic abundances of leads from five different meteorites and recent terrestrial ocean sediments are simply related. From this fact, following a series of convincing arguments, he deduces that all these leads have developed from a single primeval lead by the addition of radiogenic lead-206, lead-207 and lead-208, and that the additions of radiogenic lead commenced at a common time $(4 \cdot 55 \pm 0 \cdot 07) \times 10^{9}$ years ago. Without disputing any of these arguments, I wish to point out some interesting features of the meteoritic lead-isotope ratios which appear when they are compared with the observed ratios of these isotopes in terrestrial lead minerals.

Patterson's calculation is based on an application of Holmes's equation ${ }^{2}$, namely,

$$
\frac{y-y_{0}}{x-x_{0}}=\frac{1}{\alpha} \cdot \frac{\exp \lambda^{\prime} t_{0}-\exp \lambda^{\prime} t}{\exp \lambda t_{0}-\exp \lambda t}
$$

In this equation $x$ and $y$, and $x_{0}$ and $y_{0}$ are the ratios ${ }^{208} \mathrm{~Pb} /{ }^{204} \mathrm{~Pb}$ and ${ }^{207} \mathrm{~Pb} /{ }^{204} \mathrm{~Pb}$ at the time $t$ of isolation of lead as a mineral, and at some initial time $t_{0}$ before which lead abundances were everywhere the same. $\lambda, \lambda^{\prime}$ and $\alpha$ are constants equal to $0 \cdot 153(7) \times$ $10^{-9}(\mathrm{yr} .)^{-1}, 0 \cdot 972(2) \times 10^{-8}(\mathrm{yr} .)^{-1}$ and $137 \cdot 8$, respectively. This equation, which applies only to closed systems containing uranium and lead, has been used recently by Holmes and Cahen ${ }^{3}$ for calculating ages for many African galenas with results in apparent agreement with independently estimated geological ages, particularly in the case of palæozoic and younger minerals, where agreement was often within a few tens of millions of years.

Now if the meteorites are very old and unaltered, they should provide closed systems for uranium and lead, and this assumption in the equation should be fulfilled much more rigorously than in the case of terrestrial rocks, where the gross transport of materials has taken place. Therefore, it is interesting to try to 'date' the meteorites by the same method o calculation as has been used for galenas.

To do this I have taken as the lead ratios $x_{0}$ and $y_{0}$ in primeval lead the average of the ratios measured by Patterson for iron meteorites. These contain negligible uranium and thorium and therefore may represent the lead with which the members of the solar system were originally endowed. I have used his ocean sediment lead ratios for defining the presentday isochron and thus evaluate $t_{0}$. This gave $t_{0}=$ $4 \cdot 50_{3} \times 10^{\circ} \mathrm{yr}$., essentially the same as Patterson's result, differing slightly because I have used only three of the five values used by him. The 'ages' obtained for the three stones are given in Table 1.

Table 1. Lead Isotope RATIOS From PATterson (REF. 1) AND Table 1. CALAD ISOTOPE RATIOS FROM PATTERSON (RER.

\begin{tabular}{|c|c|c|c|}
\hline Description & $206 / 204$ & $207 / 204$ & 'Age' value* \\
\hline $\begin{array}{l}\text { Henbury, Australia } \\
\text { (1ron meteorite) } \\
\text { Canyon Diablo, } \\
\text { Arizona } \\
\text { (iron meteorite) } \\
\text { Ocean sediments } \\
\text { Nuevo Laredo; Mexico } \\
\text { (stone meteorite) } \\
\text { Forest City, Iowa } \\
\text { (stone meteorite) } \\
\text { Modoc, Kansas } \\
\text { (stone meteorite) }\end{array}$ & $\begin{array}{r}9 \cdot 55 \\
\\
9 \cdot 46 \\
19 \cdot 0 \\
50 \cdot 28 \\
19 \cdot 27 \\
19 \cdot 48\end{array}$ & $\left.\begin{array}{l}\begin{array}{l}10 \cdot 38 \\
10 \cdot 34 \\
15 \cdot 8\end{array} \\
34 \cdot 86 \\
15 \cdot 96 \\
15 \cdot 76\end{array}\right\}$ & $\begin{array}{l}\text { Primeval lead } \\
\text { Zero by def'n. } \\
330 \text { m.y. } \\
5 \text { m.y. } \\
-420 \text { m.y. }\end{array}$ \\
\hline
\end{tabular}

* Calculated time at which uranium lead ceased to be added to * Calculated time at whic
the lead in the meteorite.
If the three stones had remained isolated, closed systems until recent times, all ages should be zero within experimental error. This is the case for the Forest City meteorite, which (perhaps by coincidence) is the only one of the three which has been dated at 4,000-4,500 million years by both the potassiumargon and rubidium-strontium methods. We therefore know that it has remained unaltered for the last 85-90 per cent of its lifetime, at least.

If these were terrestrial lead minerals, we would say that Nuevo Laredo lead had been isolated from the greater part of its uranium about 330 million years ago, and that Modoc lead was anomalous ${ }^{4}$ (cf. Houtermans's ${ }^{5} J$-type lead), having been exposed to much larger proportions of uranium during the recent past than during the rest of its history. Evidence for the latter conclusion would then be considered to be well outside experimental error. For example, Houtermans ${ }^{5}$ has shown by direct measurements of lead-210 that cotunnite lead from Vesuvius, which gives a negative age of only about 200 million years, has been recently in an environment ten times richer in uranium than the average source rock for all leads.

Thus although the meteoritic isotope ratios fit a single isochron so closely that they provide an excellent estimate of the age of the Earth-meteorite system, they deviate from it by amounts that would be considered clearly significant in the case of terres. trial lead minerals. Assuming that the reproducibility of the meteorite lead analyses is as good as that generally obtained for ore leads, one must conclude that either the three stones were formed at significantly different times (corresponding to $t_{0}$ values differing by a few tens of millions of years), or that. Nuevo Laredo and Modoc have experieneed chemical alteration. in the past few hundred million years. The second possibility would demand that potassiumargon measurements on these two meteorites give young ages since radiogenic argon would escape at the time of alteration, and that Nuevo Laredo contains less uranium than would be calculated from its radiogenic lead content. Suess and Urey ${ }^{6}$ have recently directed attention to the fact that present experimental evidence does suggest a defieiency of uranium in Nuevo Laredo.

Therefore the isotopic data of Patterson could be interpreted as indicating recent chemical alteration of some stone meteorites.

Physics Department,

University of Toronto, Nov. 2.

1 Patterson, C., Geochim. et Cosmochim. Acta, [10, 230 (1956)].

Holmes, A., Nature, 15\%, 680 (1946).

'Holmes, A., and Cahen, L., Colon. Geol. Min. Resources, 5, 3 (1955).

4 Russell, R. D., Farquhar, R. M., Cumming, G. L., and Wilson. J. T., Trans. Amer. Geophys. Union, 35, 301 (1954).
.

${ }^{5}$ Eberhardt, P., Geiss, J., and Houtermans, F, G., Z. Phys., 141. 91 (1955).

'Suess, H. E., and Urey, H. C., Rev. Mod. Phys, 28. 53 (I95h).

\section{A Fast Method for reaching Equilibrium in the Ultracentrifuge}

THe inherent power of the equilibrium method ${ }^{1}$ for study of molecular weight, polydispersion, and activity coefficients in the ultracentrifuge has been limited by the length of time required to reach equilibrium. We have found that this time can be appreciably reduced by using the synthetic boundary cell $^{2}$ and by selecting the starting conditions-speed 